\title{
CASE STUDIES OF ENVIRONMENTAL THE QUALITY OF BUILDINGS DAMAGED BY EARTHQUAKES, PRIOR TO ADAPTIVE RECONSTRUCTION: PALAZZO MOSCARDELLI IN OFENA AND EX-COLONIA IX MAGGIO AT MONTELUCO DI ROIO, L’AQUILA, ITALY
}

\author{
ANGELA LOMBARDI ${ }^{1}$, JOHN MURPHY JR ${ }^{1}$, ANTONELLA IANNARELLI $^{2}$, \\ SIMONETTA CIRANNA ${ }^{3}$, PATRIZIA MONTUORI ${ }^{3}$ \& ELSA G. DE LEON ${ }^{1}$ \\ ${ }^{1}$ The University of Texas at San Antonio, USA \\ ${ }^{2}$ ARTA Abruzzo, Italy \\ ${ }^{3}$ Università dell'Aquila, Italy
}

\begin{abstract}
As a community responds to a case of earthquake disaster with regard to rebuilding a largely historic building rich environment, many things are considered: structural viability, remnant percentage of original structure, safety of remnant structure in which to work, assessment of its development over time, cultural value of replacing the building with facsimile of historic structure, residual value of the property, and many others. When deemed appropriate and beneficial to reconstruct a damaged historical building, one often overlooked aspect of design and planning is the assurance of environmental quality/indoor air quality. The country of Italy is a productive area for study in this regard based upon its central geological fault line that has shown a recent propensity to shift and its largely historic built environment. This research analyses two historic structures that have been damaged in the central Italy earthquake of 2009, specifically in the cities of L'Aquila and Ofena, which are planned for reconstruction and adaptive reuse. Research into the history of each structure, their uses over time, design principles, and construction methodology were completed. In addition, the testing protocol and documentation are presented, testing and sampling were completed for climatological data, and both indoor and ambient measurements for particulate counts, gases, total volatile organic compounds (VOCs), and bio aerosols. Further explanation as to the specific importance of bio-aerosol surveys is explained. The equipment utilized includes a GX-2009 Gas Detector, Bio-Pump Plus bio-aerosol analysis, Model P311 Particle Counter, a Kestrel Weather Tracker, and VOC Canister sampling. The test results are analyzed and compared to WHO exposure limits. Suggestions regarding pollutant source control for environmental quality through some proposed suggestions for reconstruction strategies are presented, as well as providing data for possible future standardized processes for pre-design analysis for the adaptive reuse of damaged historic structures.
\end{abstract}

Keywords: historic buildings, post-earthquake reconstruction, indoor air quality, environmental quality, adaptive reuse, bio aerosols, pathogens, bio organisms, radon gas.

\section{INTRODUCTION}

Designing an adaptive reuse or reconstruction project involves all the usual architectural design considerations involved with a new structure. However, there are also additional considerations that must be undertaken. In large part, these can be seen as an expanded consideration of existing conditions including water damage, mold, biological contaminants, and other contaminant sources from former space uses. Early in the project's consideration process, it would be necessary to carry out due diligence of existing environmental conditions and an environmental assessment. For example, in the USA this process would be overseen by the Environmental Protection Agency and in the EU it would be overseen by the European Council [1]. In addition, the reconstruction processes and material specifications become considerations for future environmental quality assessment for the respective project. Of 
course, when one considers both historic and earthquake-damaged structures, a higher level of complexity due to unknown factors becomes an issue. The case studies in the research herein involve buildings that are both historic and earthquake damaged, but the authors are only considering the existing conditions of the structure and their relative relationship to environmental quality/indoor air quality in situ. The first investigative step is to consider the location and history of the structures.

\subsection{History and location}

Two buildings were selected to represent two different settings to allow for some geographical variability. One building is located at the top of a large hill outside of a town of medium size, L'Aquila, Italy, and was originally located and designed during the Fascist Period to take advantage of prevailing quality ambient air. The Colonia Montana IX Maggio, at Monteluco di Roio was initially created to house children in need of convalescence, therapy or recovery from respiratory conditions [2]. As Pagano wrote in an article published in the architecture journal Casabella, in 1937, the building is an example of "healthy and simple construction ... that can be proudly included in the international literature of mountain colonias" [3]. The Colonia has undergone several use changes over time, including being an American military base in WWII, a holding facility for Dalmatia refugees, and most recently a Università dell'Aquila College of Engineering facility [4]. Also, the environmental context, which motivated the site selection for such a peculiar building type, was altered throughout time. In fact, the building was originally conceived following the principle of architectural and landscape total integration: located almost on the crest of the plateau of the hill of Roio, it marked the limit between the southern part, even today devoid of arboreal vegetation, and the northern side where a thick pinewood is standing. Until the mid-19th century, the whole hill of Roio was largely devoid of trees and was used as a pasture for animals of local farmers. At the end of the 19th century, the landscape was severely altered with a massive planting of conifers by the State Forestry Corps in order to retain the soil and prevent landslides on the road below and on the recently built railway line. Historic images of the building show its relationship with the rural context, which is free in the area immediately close to the building.

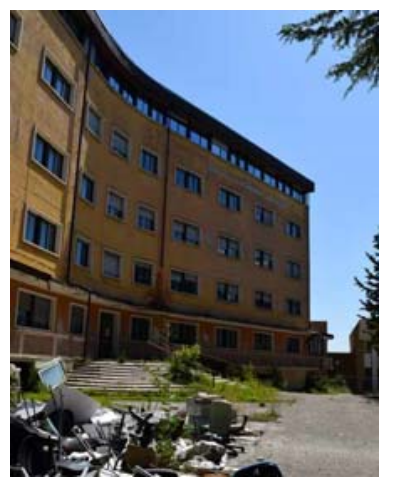

Figure 1: Ex Colonia IX Maggio, Monteluco di Roio. (Source: E.G. De Leon.)

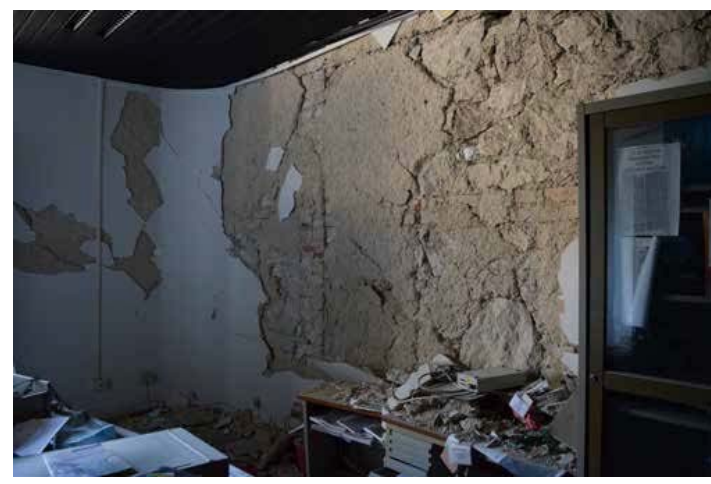

Figure 2: Office inside Colonia IX Maggio, abandoned after 2009 earthquake. (Source: E.G. De Leon.) 
Unfortunately, the site was already modified in the 1970s with the introduction of an incoherent curtain of tall evergreens, located in front of the southern front of the building, prior to the construction of a parking lot.

The other building, the Palazzo Moscardelli, is located in the historic center of the Medieval Hill town of Ofena, Italy, which was built on the ruins of the ancient Italic-Roman settlement of Ofinium on the southern slope of the Gran Sasso mountain.

The medieval fortified village still retains remnants of old bastions, some of which were turned into compact and tall houses with defensive function. Within the urban fabric, the roads rarely follow contour lines, like in most Medieval cities, but are organized following a Roman cruciform plan.

The city settlement lays north of the plateau of Navelli and is located inside the boundaries of the National Park of Gran Sasso and Laga Mountain, and the Nature Reserve of Voltigno and Angri Valley. Because of its peculiar location and climate conditions, the city environs are characterized by varied vegetation and the growth of some extremely rare plant species, such as Goniolimon italicum, also known as L'Aquila limonium, which can be found only in the inner hollows of this province, and the L'Aquila broom (Genista pulchella subsp. aquilana). Because of summer high-temperature peaks, due to the high continentality of the area, exposure to the south and hilly altitude, Ofena is known, together with Capestrano, as the 'oven of Abruzzo'.

The building is the historical property of the Moscardelli family, who were, in the past, one of the most important landowners of the area, contributing to founding the settlement on the hill during the Middle Ages. The original core of the palace dates back to the 15th century, as evidenced by several architectural details. The palace was later expanded throughout time until the 18th century, and after the 1703 earthquake. It is one of the most prominent historic monuments of the historic center of the town, being the birth place of a prominent futurist poet Nicola Moscardelli (1894-1943) [5]. The palace still remains intact, including the apartment where the poet lived, with his studio, furniture and books. Both of these buildings were significantly damaged in the earthquake of 2009.

\subsection{Condition/damage assessment and pollutant source recognition}

Assessing environmental quality in historic and damaged buildings is a complex process that should consider many facets of the original design, including structure, weatherproofing, environmental controls, and finishes. Fundamental to this assessment is the visual observation of the current state of the building. Is there any water damage? Are interior finishes stained? Does one smell odors that could be attributable to mold? Is mold seen? Is the roof system breached? Are there openings in the structure? Etc. Following the observations, testing should be employed to capture any possible airborne pollutants, hydrocarbons, particulates, bio aerosols, or volatile organic compounds. In addition, basic environmental measurements should be taken to provide background information for the point in time the samples were taken. Through the results of said testing, conclusions can be drawn about the possibility of occupant exposure to existing conditions, and thus a statement of, presumably, less-than-optimum environmental quality. The research included herein, in fact, uses these assessment strategies and the following methods were employed.

Of course, with the test results in mind, one has to evaluate the existing conditions in relation to some standards of human exposure or "acceptable risk". There are two different standards systems in place that can be considered as geographically based: USA vs. EU [6]. However, because of the location of these two case studies, researchers chose to investigate the use of the EU system and the WHO Air Quality Guidelines for Europe for their analysis. 


\section{RESEARCH METHODS}

For each building surveyed, in-situ testing was carried out under the guidance of local inspectors and building officials. In addition to visual reconnaissance throughout the building, the following testing strategies were employed.

The instrumental survey consisted of the collection of samples through the use of four instruments: GX-2009 Gas Detector, Bio-Pump Plus bio-aerosol analysis, Model P311 Particle Counter, Kestrel Weather Tracker, and volatile organic compound (VOC) Canister sampling was undertaken by ARTA Abruzzo, by Carlo Bellina Agostinoni. See Table 1 for further explanation and a summary of equipment and specific usage.

Samples for gas emissions, air particulate counts, bio-aerosols, humidity/temperature and total VOCs were taken on each of the historic structures analyzed using these instruments in 3-5 different locations and various rooms. The selection of rooms depended on the observed conditions of each, as well as the apparent "worst" conditions to create a concept of worse-case scenario. For example, locations were sought with visual confirmation of mold, high humidity, structural damage, the condition of location, and past uses. Any obvious changes of rooms since occupant departure were noted. During the instrumental survey, three out of five instruments provided us automatic results. These results are related to weather and airborne particulate counts. However, the typology of particulate samples was not ascertained. The bio-aerosol and VOC samples were captured and sent for analysis to a laboratory under the administration of ARTA Abruzzo. Figs 1-3 illustrate the sample location strategies. Researchers were unable to sample or analyze radon gas occurrence levels at either subject building. However, regional data regarding radon gas emissions are available for consideration, collected by ARTA Abruzzo [7].

Table 1: Environmental site assessment survey equipment and usage.

\begin{tabular}{|c|c|c|c|c|}
\hline \multicolumn{5}{|c|}{$\begin{array}{l}\text { Indoor Air Quality and Interior Environmental Conditions for Adaptive Reuse of Historic Structures } \\
\text { Environmental Site Assessment Survey Instruments }\end{array}$} \\
\hline \multicolumn{5}{|c|}{$\begin{array}{l}\text { The chart bellow shows instruments that will be utilized during Summer } 2016 \text { L'Aquila Campaign providing major information on the } \\
\text { hazardous substances to be surveyed. Survey time and methods. }\end{array}$} \\
\hline $\begin{array}{l}\text { Instrument } \\
\text { Name }\end{array}$ & $\begin{array}{l}\text { Instrument } \\
\text { Dimension }\end{array}$ & Instrument Goal & Survey Time & Survey Method \\
\hline $\begin{array}{l}\text { Zefon Bio- Pump } \\
\text { Plus* }\end{array}$ & $\begin{array}{l}4.3 / 8^{*}(w) \times 2.75^{*} \\
(h) \times 8^{*}(d)\end{array}$ & $\begin{array}{l}\text { Multi-purpose particle collection device. It } \\
\text { collects viable and non-viable bio-aerosols. } \\
\text { for example: mold spores, pollen, insect } \\
\text { parts, skin cell fragments, fibers, and } \\
\text { inorganic particulate. }\end{array}$ & $\begin{array}{l}\text { Uses predetermine } \\
\text { sampling times of } 1,2,5 \text {, } \\
\text { or } 10 \text { minutes. }\end{array}$ & $\begin{array}{l}\text { Identify location for each } \\
\text { room of the structure, } \\
\text { which will be indicated on } \\
\text { a proper key floor plan. } \\
\text { These will also be }\end{array}$ \\
\hline Kestrel 4000 & $\begin{array}{l}\text { Same dimension } \\
\text { as a remote } \\
\text { control. }\end{array}$ & $\begin{array}{l}\text { It is set up to display } 10 \text { measurements or } \\
\text { calculations in different modes. It measures } \\
\text { the following elements: wind speed, } \\
\text { temperature, wind chill, humidity, heat } \\
\text { index, dew point wet bulb, barometric } \\
\text { pressure, altitude, and density altitude. }\end{array}$ & $\begin{array}{l}\text { Few seconds to a } \\
\text { maximum of } 20 \text { minutes. }\end{array}$ & $\begin{array}{l}\text { documented through } \\
\text { photographs. } \\
\text { Construction techniques } \\
\text { and interior materials } \\
\text { finishes will be described. } \\
\text { Take the sample } \\
\text { according to the function }\end{array}$ \\
\hline $\begin{array}{l}\text { Model P311 } \\
\text { Handheld } \\
\text { Particle Counter }\end{array}$ & $\begin{array}{l}r^{*} \times 3.5^{*} \times 1.9^{*} \\
(L \times W \times H)\end{array}$ & $\begin{array}{l}\text { The Air Technology P311 handheld particle } \\
\text { counter measures } 0.3 \text { um to } 5.0 \text { um with a } \\
\text { flow rate of } 0.1 \text { CFM ( } 2.83 \text { LPM). }\end{array}$ & $\begin{array}{l}1 \text { second to } 99 \text { minutes } 59 \\
\text { seconds. This sampling } \\
\text { time is configurable. }\end{array}$ & $\begin{array}{l}\text { of each instrument. All of } \\
\text { the instruments will be } \\
\text { utilized in the same }\end{array}$ \\
\hline $\begin{array}{l}\text { GX-2009 Gas } \\
\text { Monitor }\end{array}$ & $\begin{array}{l}27^{*} \times 3^{*} \times 1^{*} \\
(H \times W \times D)\end{array}$ & $\begin{array}{l}\text { It uses an advanced detection system } \\
\text { consisting of four gas sensors; the personal } \\
\text { four-gas monitor detects the presence of } \\
\text { combustible gas, oxygen }\left(\mathrm{O}_{2}\right) \text {, carbon } \\
\text { monoxide (CO), and hydrogen sulfide }\left(\mathrm{H}_{2} \mathrm{~S}\right) \\
\text { simultaneously. }\end{array}$ & $\begin{array}{l}\text { The gas monitor response } \\
\text { time takes within } 30 \\
\text { seconds. }\end{array}$ & location. \\
\hline $\begin{array}{l}\text { TVOC Stainless } \\
\text { Canister* and } \\
\text { Assay } 580^{*}\end{array}$ & Basket size. & $\begin{array}{l}\text { TVOC and 4-PCH canister measures the } \\
\text { organic components. The Assay } 580 \text { will } \\
\text { measure the formaldehyde. }\end{array}$ & $\begin{array}{l}\text { Time is between } 4.8 \text { hours } \\
\text { depending on the } \\
\text { dimension of the canister. }\end{array}$ & \\
\hline
\end{tabular}




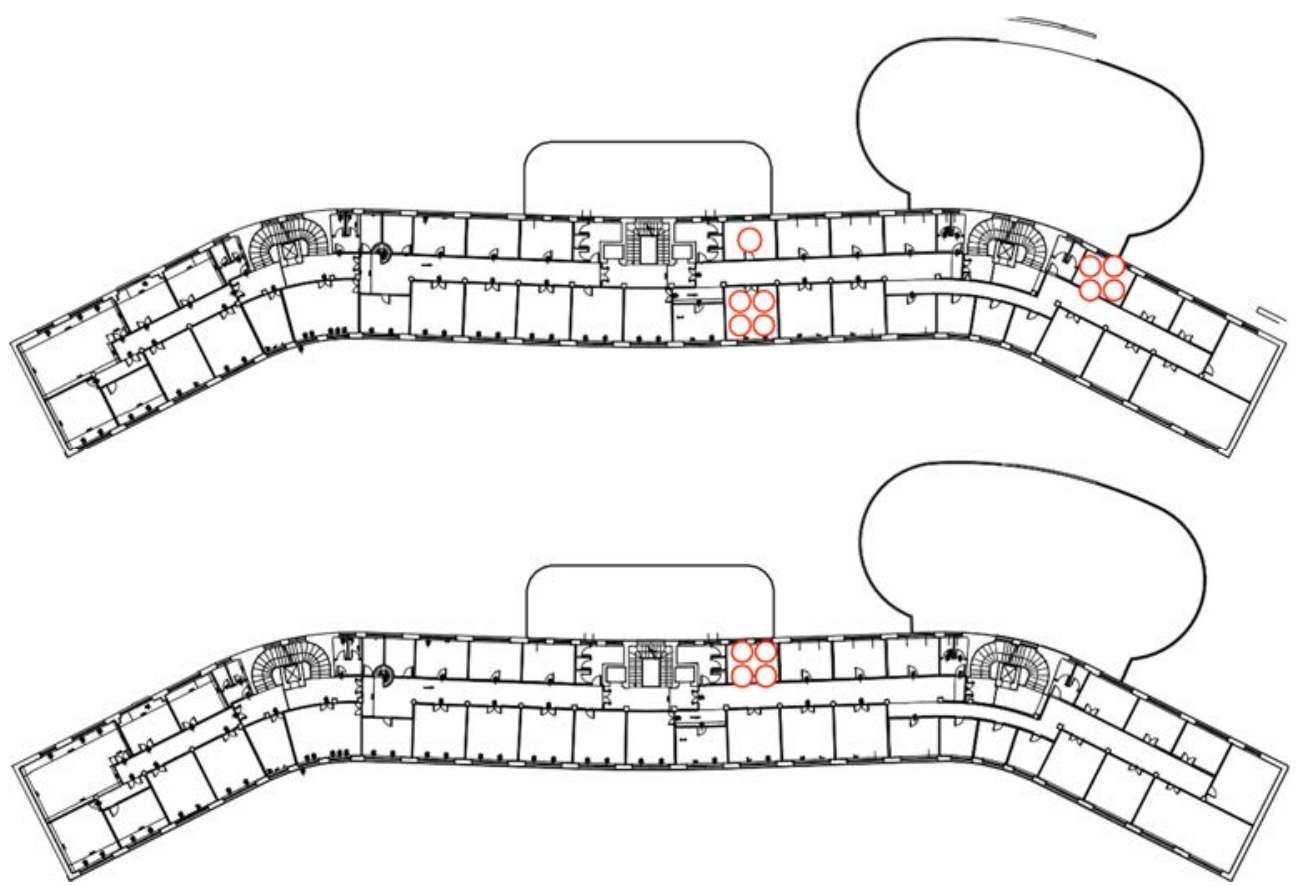

Figure 3: Floor sampling locations, Colonia building.

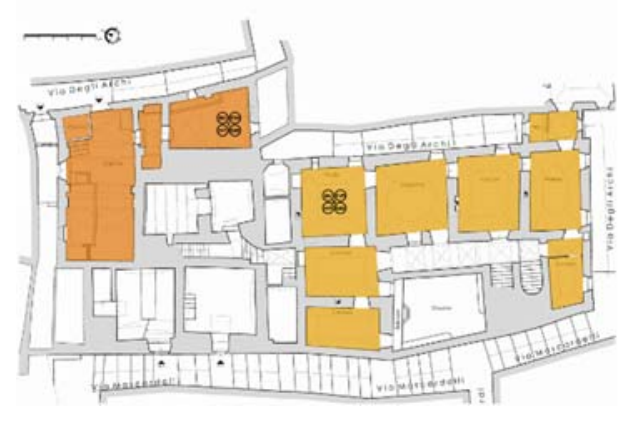

Figure 4: $1^{\text {st }}$ floor sampling locations, Palazzo Moscardelli.

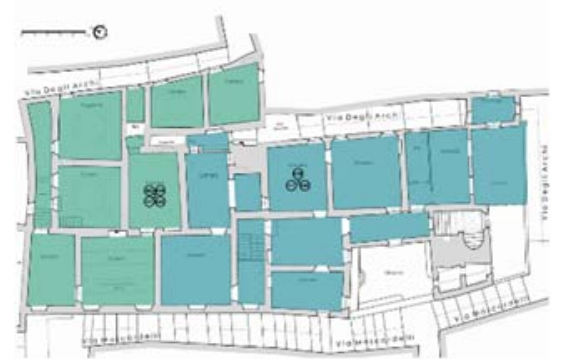

Figure 5: $2^{\text {nd }}$ floor sampling locations, Palazzo Moscardelli.

\section{RESULTS}

As one can imagine, initial results analysis involves straight data from equipment readings and/or scientific/microscopic sample readings, which are generally straightforward reports of measurements taken. The following sections present tables of such measurements taken from the two subject buildings. The secondary portion of the research "analysis" to complete the results report involves a comparison of the test results to some lists of acceptable risk standards for the pollutants found. 


\subsection{Samples results}

Table 2 illustrates the equipment utilized and environmental data collected for both buildings. Table 3 presents the particulate counts taken at both buildings. The other onsite "real-time" sampling taken was through the use of a RK Instrument GX-2009 Gas Detector. In both buildings sampled, by and large, no discernible levels of $\mathrm{H}_{2} \mathrm{~S}, \mathrm{CO}$, LEL, or $\mathrm{O}_{2}$ were found. Two exceptions to this were: 1) a $\mathrm{CO}$ reading of $18 \mathrm{ppm}$ ambient air condition between Colonia building and parking lot; and 2) a $\mathrm{CO}$ reading of $2 \mathrm{ppm}$ near a heating unit that was not functioning. In addition, Figs 5 and 6 show the laboratory analysis results of VOC canister testing for ambient air conditions and indoor air conditions for the Colonia in Monteluco di Roio. Bio-aerosol samples were taken and the results are summarized in several tables for each sample room location. The results are discussed in section 3.2.4. However, due to the space limitations of this paper, summary tables were included herein, but all summary tables are available upon request. Actual radon assay samples were not undertaken; however, a wider approach has been adopted for radon gas emission assessment, using data provided by ARTA Abruzzo which has been monitoring all the Abruzzo region area since 2009 [7].

\subsection{Comparative analysis to standards}

As state previously, this secondary analysis step includes taking the resultant measurements and comparing them to the accepted risk levels of pollutant compounds or materials. For this purpose, after reviewing the applicable laws and guidelines with associated standards shown in Table 4, the authors chose to use the WHO guidelines for indoor air quality: selected pollutants (WHO Office for Europe, 2000). While a complex overall assessment of actual physiological risk may include guidance and, thus, more than the actual sample result

Table 2: Environmental conditions data.

\begin{tabular}{|l|r|r|r|r|r|}
\hline \multicolumn{7}{|c|}{$\begin{array}{c}\text { Kestrel 4000 Weather } \\
\text { Tracker Samples }\end{array}$} \\
\hline Measurement & $\begin{array}{c}\text { Sample } \\
\text { No.1 }\end{array}$ & $\begin{array}{c}\text { Sample } \\
\text { No.2 }\end{array}$ & $\begin{array}{c}\text { Sample } \\
\text { No.3 }\end{array}$ & $\begin{array}{c}\text { Sample } \\
\text { No. 4 }\end{array}$ & Ambient \\
\hline Site: Colonia Poggio di Roio & 1676.00 & 1686.00 & 1714.00 & & 1691.00 \\
\hline Altitude & 28.70 & 28.69 & 28.67 & 28.67 & 28.69 \\
\hline Barometric Pressure & 70.20 & 73.00 & 72.00 & 72.30 & 72.30 \\
\hline Wet Bulb & 67.30 & 67.60 & 68.60 & 70.50 & 66.90 \\
\hline Dew Point & 85.30 & 87.80 & 88.90 & 90.00 & 89.10 \\
\hline Heat Index & 64.60 & 65.00 & 55.10 & 60.20 & 55.50 \\
\hline Humidity & 80.90 & 83.10 & 84.20 & 84.70 & 85.80 \\
\hline Temperature & 2852 & 2851 & 2862 & 2842 & \\
\hline Site: Palazzo Moscardelli & \multicolumn{7}{|c|}{} & & & \\
\hline Altitude & 27.52 & 27.52 & 27.51 & 27.53 & \\
\hline Barometric Pressure & 70.7 & 73.8 & 70.7 & 70.9 & \\
\hline Wet Bulb & 67.4 & 67.4 & 69.5 & 65.1 & \\
\hline Dew Point & 83.1 & 87.4 & 82.6 & 83.7 & \\
\hline Heat Index & 64 & 63.8 & 60.6 & 63.8 & \\
\hline Humidity & 79.8 & 83.5 & 80.5 & 80.4 & \\
\hline Temperature &
\end{tabular}


Table 3: Particulate count measurements.

\begin{tabular}{|c|c|c|c|}
\hline \multicolumn{4}{|c|}{ Airy Technology Model P311 Particle Counter } \\
\hline $\begin{array}{l}\text { Particle Counter Samples } \\
\text { Sample No. }\end{array}$ & CNT & $\Sigma$ & $\Delta$ \\
\hline \multicolumn{4}{|c|}{ Site: Colonia Poggio di Roio } \\
\hline \multirow[t]{3}{*}{ Sample Ambient Air } & $0.3 \mu \mathrm{m}$ & 202371 & 178766 \\
\hline & $0.5 \mu \mathrm{m}$ & 23605 & 23082 \\
\hline & $5.0 \mu \mathrm{m}$ & 523 & 523 \\
\hline \multirow[t]{3}{*}{ Sample 1} & $0.3 \mu \mathrm{m}$ & 240173 & 207936 \\
\hline & $0.5 \mu \mathrm{m}$ & 32237 & 31189 \\
\hline & $5.0 \mu \mathrm{m}$ & 1048 & 1048 \\
\hline \multirow[t]{3}{*}{ Sample 2} & $0.3 \mu \mathrm{m}$ & 223771 & 193895 \\
\hline & $0.5 \mu \mathrm{m}$ & 29876 & 28961 \\
\hline & $5.0 \mu \mathrm{m}$ & 915 & 915 \\
\hline \multirow[t]{3}{*}{ Sample 3} & $0.3 \mu \mathrm{m}$ & 208961 & 142426 \\
\hline & $0.5 \mu \mathrm{m}$ & 66535 & 58766 \\
\hline & $5.0 \mu \mathrm{m}$ & 7769 & 7769 \\
\hline \multirow[t]{3}{*}{ Sample 4} & $0.3 \mu \mathrm{m}$ & 211819 & 142271 \\
\hline & $0.5 \mu \mathrm{m}$ & 69548 & 61717 \\
\hline & $5.0 \mu \mathrm{m}$ & 7831 & 7831 \\
\hline \multicolumn{4}{|l|}{ Site: Palazzo Moscardelli } \\
\hline \multirow[t]{3}{*}{ Sample 1} & $0.3 \mu \mathrm{m}$ & 114723 & 95828 \\
\hline & $0.5 \mu \mathrm{m}$ & 18895 & 15397 \\
\hline & $5.0 \mu \mathrm{m}$ & 3498 & 3498 \\
\hline \multirow[t]{3}{*}{ Sample 2} & $0.3 \mu \mathrm{m}$ & 129263 & 117775 \\
\hline & $0.5 \mu \mathrm{m}$ & 114488 & 10822 \\
\hline & $5.0 \mu \mathrm{m}$ & 666 & 666 \\
\hline \multirow[t]{3}{*}{ Sample 3} & $0.3 \mu \mathrm{m}$ & 157531 & 145659 \\
\hline & $0.5 \mu \mathrm{m}$ & 11872 & 10944 \\
\hline & $5.0 \mu \mathrm{m}$ & 928 & 928 \\
\hline \multirow[t]{3}{*}{ Sample 4} & $0.3 \mu \mathrm{m}$ & 124915 & 113076 \\
\hline & $0.5 \mu \mathrm{m}$ & 11839 & 11203 \\
\hline & $5.0 \mu \mathrm{m}$ & 636 & 636 \\
\hline
\end{tabular}

measurements, researchers use the method of comparing resultant numbers to guideline values. From these guidelines, "the numerical guideline values and the risk estimates for carcinogen should be regarded as the shortest possible summary of a complex scientific evaluation process." In addition, "for some pollutants no guideline values are recommended, but risk estimates are indicated instead" [8].

\subsubsection{Particulate data collection assessment}

Particulate data collected for both buildings shows that the ambient conditions are very similar to the indoor environment. However, there are unintended limitations with the particulate counter equipment with respect to being able to compare to guidelines because 


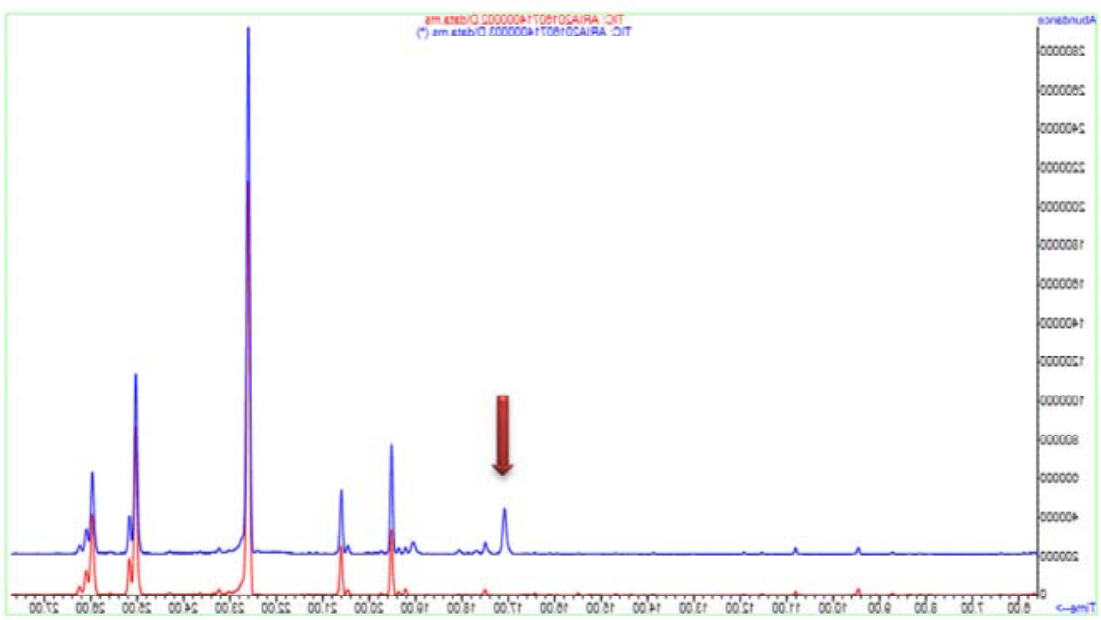

Figure 6: Colonia building - overlay of the gas chromatographic profiles related to base line (red) and to one sample inside building (blue).

Table 4: Guidelines for allowable concentrations.

\begin{tabular}{|l|l|}
\hline \multicolumn{2}{|c|}{ Guidelines for Allowable Concentrations } \\
\hline \multicolumn{2}{|c|}{ (Per WHO, 2000) } \\
\hline Contaminant & $\begin{array}{l}\text { Max Allowable } \\
\text { Concentration }\end{array}$ \\
\hline Formaldehyde & $27 \mathrm{ppm}$ \\
\hline Total Volatile Organic Compounds & $500 \mu \mathrm{g} / \mathrm{m} 3$ \\
\hline 4-PCH & $6.5 \mu \mathrm{g} / \mathrm{m} 3$ \\
\hline $\begin{array}{l}\text { Carbon } \\
\text { Monoxide }\end{array}$ & $9 \mathrm{ppm}$ and no greater than \\
& $2 \mathrm{ppm}$ above outside value \\
\hline
\end{tabular}

the particulate guidelines are units of microgram per cubic meter (i.e. mass). The equipment used measures only the count of particulates based upon size (in microns) per cubic meter of air, and conversion to mass-based units would require ascertaining the density of the particulates, with assumed values of porosity, shape and volume. This data, and therefore the conversion, is beyond the scope of this research. However, there is anecdotal value in ascertaining that the ambient air and the indoor air are of somewhat similar count; therefore, it can be concluded that no increase of indoor particulates over time has occurred. Thus, it can be said that adequate ventilation has occurred over the same time.

\subsubsection{Gas data collection assessment}

Hand-held gas meters are, obviously, intended to inform occupants of the possible existence of harmful gases at a specific point in time. As indicated above, the meter readings for this 
research were largely rated as showing "no discernible measurement of harmful gasses" with two exceptions. For one incident, because the equipment was not functional (and space unoccupied), the slight $\mathrm{CO}$ reading of $2 \mathrm{ppm}$ at the Palazzo Moscardelli can most likely be attributed to residual off-gassing from heating equipment from uses in the past. Relative to any reuse of space, such a situation would most certainly be mitigated through the replacement of the heating system, something likely achievable through architectural redesign and construction process anyway. For the other incident, at the Colonia building a $10 \mathrm{ppm}$ reading of $\mathrm{CO}$ was shown near the parking lot in an ambient conditions situation. Presumably, external vehicle traffic in said parking lot provides a combustion source for said "slight reading", and is regularly dissipated through wind and environmental convection. However, being slightly over the CO guideline for allowable levels (see Table 6), mitigation measures are called for in any redesign of the outside space adjacent to the Colonia building site due to the proximity to the building and the high potential of infiltration into the interior space.

\subsubsection{VOC canister data assessment}

As Figs 5 and 6 indicate, the base line, taken outside the building, shows that outdoor air is rich in VOCs, both of natural and anthropic origin; therefore, its gas chromatic profile graph is characterized by a multitude of peaks.

A useful overlay of interior and exterior gas chromatic profile graphs emphasizes that no presence of substances directly attributable to the building's internal sources can be identified. This is a typical condition of places with abundant air exchange and with no emissive sources. The Colonia's building, damaged by the earthquake, has doors and windows in bad conditions, sometimes even missing; cracks in the exterior walls are also clearly visible. These conditions prevent the building from being considered for 'confined spaces'.

The only peak present in the sample gas chromatic profile graph, highlighted with a red arrow in Fig. 6, is an Alkane. Alkanes are known for applications as solvents and as important components of crude oil, diesel, and gasoline [9]. Presumably, it can be concluded that the source of Alkane compounds is directly tied to the parking lot usage by combustion vehicles, as well as the asphalt paving materials used for the surface of the parking lot. This supports the gas meter results discussed earlier.

Utilized techniques for the sampling and analysis of VOCs proved to be extremely sensitive, bringing researchers to require the need to appropriate sealing during renovation works in order to drastically decrease the level of 'uncontrolled' air exchange with the outdoors. Further, sample analysis and sampling took to the conclusion that the development of sampling design and scheduling would be extremely effective in order to undertake an extensive campaign.

\subsubsection{Bio-aerosol data assessment}

The summarized data results (as stated earlier, data not included herein due to space limitations) indicate that samples R1, R2, R3, and R4, taken in the Colonia building at Poggio di Roio, contain very few pollen species, aside from the prevailing species Pinaceae, then Graminaceae, Cupressaceae and Alnus.

The high presence of Pinaceae pollens is related to the massive presence of pine wood which have their blooming period in the month of July. Cupressaceae and Alnus, on the contrary, bloom during Spring; therefore, the detected presence of their pollens is most probably due to a lack/absence of air exchange in the building. Because of their dimensions, from 15 to 200 micrometers, pollens can easily penetrate indoor spaces by air, as in this case, 
or through transport via shoes, clothes, animals or even objects. During blooming periods, indoor pollen concentration is lower than outdoor concentration; in order to understand the relationship between the indoor and outdoor environment, data recording the period of permanence in the air of the most allergenic pollens were extracted from ARTA Abruzzo's bulletin in the days the samples were taken. The bulletin data sheet confirms that Cupressaceae and Alnus pollens were not present in the outdoor environment.

In order to better understand the effects on human health of the presence of different pollens, Table 5 provides some interpretation data.

Allergenic power is the capacity of causing allergic reactions depending on the pollen grain allergenic degree. Pollen's allergenic degree depends also on the area's climatic condition during pollens dispersion. In urban areas, for example, the presence of atmospheric factors such as pollution can contribute to a higher sensitization to airborne pollen.

Other data indicates, as researchers visually assessed, the presence of spores from several molds, in medium concentration. Alternaria, which is the most allergenic molds in the Italian climate, is present in very low concentrations. A presence of Alternaria spores is also present in the outdoor environment, with higher values of 53.73 spores $/ \mathrm{m}^{3}$ on July 11 and 104.47 spores $/ \mathrm{m}^{3}$ on July 12 , as extracted from the ARTA bulletin.

Samples taken in the "Palazzo Moscardelli" in Ofena show an increased variety of pollens and mold spores in comparison with the Monteluco di Roio building, with a moderate increase of their concentrations throughout the space. Generally, the presence of pollens of summer blooming plant species, in accordance with the sampling period (July), were detected.

Knowledge of Ofena's climate and varied vegetation is necessary to interpret data results. Numerous pollens include some allergenic species such as Graminacae, Cupressacae and Urticacee, rendering the indoor spaces a place for potential allergies.

Comparison with the ARTA bulletin also shows that some detected pollens are attributable to the spring season, such Alnus, Cupressaceae, Corylaceae and Populus, most probably because rooms are not subject to adequate air exchange.

The presence of several molds species whose proliferation is related with summer high temperatures and high humidity is noteworthy; in particular, the high percentage of humidity enhances the growth of different molds species. These molds, such as Alternaria, Cladosporium, Torula, Fusarium, Leptosphaeria, Epicoccum, and Pleospora are causes of allergies. In particular, in Italy the most allergenic molds are: Alternaria (growing on decomposing fruit and vegetables and in extremely humid spaces), Cladosporium, Aspergillus, and Penicillium. Some of these spores are characterized by a unique form and

Table 5: Interpretive bio-aerosol data.

\begin{tabular}{|c|c|c|}
\hline Pollens & Allergenic power & Blooming period \\
\hline Pinaceae & Low & April-July \\
\hline Graminaceae & From low to very high & May-October \\
\hline Cupressaceae & From high to very high & January-April \\
\hline Betulaceae (Alnus) & High & February-April \\
\hline Fagaceae & From low to medium & April-July \\
\hline Umbelliferae & Low & \\
\hline Compositae (Artemisia) & Medium & April-July \\
\hline $\begin{array}{l}\text { Chenopodiaceae } \\
\text { Urticaceae }\end{array}$ & $\begin{array}{l}\text { From low to medium } \\
\text { Very high }\end{array}$ & May-October \\
\hline Spores & Allergenic degree & Dispersion period \\
\hline Alternaria & Very high & May-November \\
\hline
\end{tabular}


dimension to be able to penetrate deeply into the respiratory tract, reaching lungs and pulmonary alveoli. Inhalation of the spores of Alternaria, for example, is one of the causes of bronchial asthma.

Pollens and mold-rich varieties detected in indoor spaces let us also understand that the building is not properly sealed from the outdoor environment. Not inhabited since the 2009 earthquake, Palazzo Moscardelli's existing windows and door openings are historically typical in that they are not efficiently sealed. Such data collection indicate that indoor air is both polluted by water-intrusion-related mold development and substances that are to be considered allergenic - a condition showing a much larger risk than the situation existing in Monteluco di Roio.

As is the case for molds, the main effects caused by pollens on human health can be related to specific allergies to the substance, known as pollinosis. Allergies develop when pollen concentrations reach values generating varied symptoms such as conjunctivitis, respiratory tract inflammation, coughing, sore throat, asthma, continuous secretion from the nose, etc. Usually periods of pollinosis are limited to blooming periods of the specific plant species generating allergies.

Confined spaces can be an effective shelter for those people who suffer from pollen allergies, as long as you can limit indoor concentrations of bio contaminants. Allergenic substances may exist due to poor air exchange based on poor natural ventilation strategies designed into the architecture, or based upon the non-functionality of the natural ventilation strategies. In either case, mitigation strategies should be employed during the redesign of the space to be reconstructed or adaptively reused. This is a priority in the case of Palazzo Moscardelli in Ofena.

\subsubsection{Radon gas assessment}

As was indicated earlier, no Radon gas samples were taken. However, historic data indicates regional predominant Radon levels of $393 \mathrm{~Bq} / \mathrm{m}^{3}$ as the maximum value in L'Aquila and $115 \mathrm{~Bq} / \mathrm{m}^{3}$ as the maximum value in Ofena.

Although at the present time no regulations have been established for Radon concentration limits in residences or public buildings in Italy, a Recommendation of the European Commission 90/143/EURATON of 1990 established some thresholds: $400 \mathrm{~Bq} / \mathrm{m}^{3}$ is the maximum acceptable value beyond which some remedy actions need to be undertaken; 200 $\mathrm{Bq} / \mathrm{m}^{3}$ is the design value for new constructions; and $500 \mathrm{~Bq} / \mathrm{m}^{3}$ for working places. The latter is a value established by the 2000 national legislative decree $241 / 2000$. According to existing guidelines and regulation of both the areas show radon levels below risk values (ARTA Abruzzo [7]). However, recent studies, in particular the ones of Giampaolo Giuliani, a researcher at the Gran Sasso particle physics laboratory, affirm that there is typically a pre-existing (pre-earthquake) condition with rising levels of radon gas bottled up in the Earth's cavities and cracks. These bottled-up radon gases are often released via the earthquake's tectonic plate shifting. Therefore, radon measurement should be undertaken on a wider scale by ARTA Abruzzo, the local Agency for the Protection of the Environment. With this in mind, it would also be advisable that the buildings under analysis could be selected by ARTA as case studies. Subsequently, architectural design considerations can be suggested by our research team for Radon gas existence for any area reconstruction projects.

\section{CONCLUSIONS}

The ultimate point of extension from the above analysis is a collection of recommendations for adjusting the environmental conditions in these architectural spaces, as examples of architectural design suggestions for similar post-earthquake, historic structures destined for 
the adaptive reuse or rehabilitation in general. These recommendations are intended to eliminate respective pollutant sources or management thereof if removal/elimination is not a realistic option. Three categories of situations are addressed here: allergenic potential, Radon exposure potential, and natural compounds or biomaterials, particulate exposure/inhalation and toxic or carcinogenic/volatile organic compound pollutant exposure.

\subsection{Allergenic potential}

Given that the data shows naturally occurring biological evidence of pollens and other allergenic compounds, it can be said that the adaptive redesign of any space under these conditions should consider better controlling the indoor environment for allergenic potential through filtration systems. Whether the climate justifies for cooling indoor air as well is a separate design decision. However, filtration would be suggested in either case to lessen the potential that occupants will be negatively affected by inhalation of, or otherwise coming into contact with, biological compounds and allergens. HEPA filter usage and electronic filter media would be a component of the solution in addition to heat exchange capture between exhaust air and intake air in cold climates.

\subsection{Radon exposure potential}

Because, historically, radon gas is found in these two building site locations, it is recommended that during the re-design processes a radon gas assay would be used to confirm the existence of radon, and mitigation strategies would be designed into the project's development. Most likely, isolation of the ground floor from the upper floors and point collection/exhaust/evacuation systems would be designed and implemented as needed. In some occasions, passive design solutions for such exhaust can suffice. However, the ability to install mechanical assistance for exhaust at a later date is necessary.

\subsection{Biomaterials and natural compounds}

Heavy molds found were visually related to apparent water intrusion, resultant from a damaged roof or water runoff route. Because there is no record of a mold problem prior to the event, it can be assumed that this change in building structure was the result of the earthquake shifting the structure. Regardless of the cause, this situation indicates the need for water-intrusion remediation, as well as detoxification and dry-out processes prior to any re-construction or adaptive reuse. The encapsulation of any mold should not be viewed as adequate due to the ability of mold to continue to grow and "bleed" through structure materials at a later date, coming into contact with future occupants.

\subsection{Volatile organic compounds (VOCs), gases, and particulate assessment}

As the results indicate, there are some low levels of Alkane in existence in one of the sample buildings. By investigation, it would appear that this is related to the proximity to the external parking lot facilities. Suggested mitigation is to relocate the parking facility to limit the potential of these Alkane compounds infiltrating into the indoor environment, and affecting the intact environmental context. Particulate count (exterior ambient air sample) and CO gas existence at the same location substantiate the need for such mitigation.

\subsection{Summative concluding statement}

The two buildings surveyed showed different environmental conditions, construction technologies and materials, as well as different condition assessments. Although a 
comparative analysis of the data is difficult to undertake, the instrumental survey offers us some important suggestions. As a designer, it is an important and environmentally responsible point of design development that one considers the environmental quality before and after redesign or adaptive reuse completion. In fact, there is a strong argument that when external air is introduced into the indoor environment by way of architectural design (i.e. natural convection by design) or by mechanical methods, or an existing indoor pollutant is not mitigated, there is an implied premises liability by a property owner [10], [11]. These researchers suggest that this liability could easily be extended to errors and omissions relative to the designer. Regardless of the actual liability risks in design, it is ethical that the design takes into account any risks that may be seen regarding a healthy indoor environment. This includes specifying future material design selections that are not VOCs, or any other known contaminants. That being the case, it is strongly suggested that adaptive reuse designers consider the following sequence of design preparations:

- Carry out a site-specific environmental impact investigation.

- Test site (exterior ambient and indoor) for present gases, VOCs, particulate matter, bio aerosols, Radon gas, and other possible contaminant materials (e.g. Asbestos, lead paint, etc.).

- Analyze sample results to evaluate risk evidence.

- Design mitigation plans for each known contaminant.

- Specify healthy materials for adaptive design.

\section{ACKNOWLEDGEMENTS}

Our thanks to the Superindency of l'Aquila, in particular the Architect Valerio Piovanello, who identified Palazzo Moscardelli, Ofena, as a possible ideal case study, and we also thank Mr Sergio Adriani, owner and manager of the Ofena property, who not only allowed us to access the building, but shared with us all the documentation paperwork produced after the 2009 earthquake damages. Special thanks to ARTA Abruzzo, the Regional Agency for the Protection of the Environment; in particular, the Director of l'Aquila facility, Dr Virginia Lena and Carlo Bellina Agostinoni, who took care of the canister samples and provided useful data interpretation and advice.

\section{REFERENCES}

[1] Murphy, J., Indoor air quality and interior environmental conditions for adaptive reuse of historic structures: A case for research and development of guidelines. Indoor Air 2016: 14th International Conference on Indoor Air Quality and Climate Proceedings, Ghent, Belgium, 2016.

[2] Pandolfi, E., Ettore Rossi (1894-1968) Architetto del Movimento Moderno, Metauro Edizioni: Pesaro, 2013.

[3] Pagano, G., Una colonia montana. Casa Bella, p. 116, 1937.

[4] Morganti, R., Tosone, A. \& Cocciolone, S., Colony IX May to the Sea's People in L'Aquila. A particular example of thirty years architecture. 5th International Conference on Hazards and Modern Heritage, Sarajevo, 22-24 Apr. 2013, pp. 283296, 2013.

[5] De Iulis, G., Balena Arista, F., Valentini, E. \& Lepidi, M., Palazzo Moscardelli. Immobile vincolato ex dlgs 42/2004. Progetto per la riparazione ed il recupero a seguito del sisma del 6 aprile 2009 aggregato $n$. 70. Technical Report, 2010.

[6] Murphy, J.D., Orlandi, J. \& Lombardi, A., Indoor air quality assessment in adaptive reuse of historic buildings: An overview and comparison of standards and regulations 
72 Sustainable Development and Planning IX

in Europe and the USA. SUDEP: International Sustainable Development on Economy and Planning, Conference Proceedings, Jul. 2016.

[7] ARTA Abruzzo, Campagne di misura del radon nelle abitazioni ed in altri edifici della Regione Abruzzo. Prospetto riassuntivo dei dati disponibili (Apr. 2012). Technical Report, 2012.

[8] Danzon, M. (ed.), Air Quality Guidelines for Europe, 2nd ed., WHO Regional Publications, European Series, No. 91, 2000.

[9] Torin McCoy, J., Toxicology Group, Habitability and Environmental Factors Division, Johnson Space Center, National Aeronautices and Space Administration. Spacecraft Maximum Allowable Concentrations for Selected Airborne Contaminants: Volume 5, Houston, TX, 2008. www.nap.edu/read/12529/chapter/9

[10] Murphy, J., O'Marra, B. \& Jensen, D., Indoor air quality and the issue of products liability. Is Air a Product? An International Conference on Healthy Buildings in Mild Climates, Milan, Italy. Vol. 3, pp. 1769-1773, Sept. 1995.

[11] Murphy, J., Jensen, D. \& O'Marra, B., Exploring the concept of building owners' premises liability with respect to indoor air quality and the need for governmental standards. Indoor Air - An Integrated Approach, eds L. Morawska, N.D. Bofinger \& M. Maroni (Conference proceedings), Elsevier Science Ltd. UK, pp. 445-449, 1994. 